\title{
Genetic variation in and spatial structure of natural populations of Dipterocarpus alatus (Dipterocarpaceae) determined using single sequence repeat markers
}

\author{
N.M. Tam ${ }^{1,2}$, V.D. Duy ${ }^{1}$, N.M. Duc 2 , V.D. Giap ${ }^{3}$ and B.T.T. Xuan ${ }^{2}$ \\ ${ }^{1}$ Department of Experimental Taxonomy \& Genetic Diversity, Vietnam \\ National Museum of Nature, \\ Vietnam Academy of Science and Technology (VAST), \\ Cau Giay, Hanoi, Vietnam \\ ${ }^{2}$ Department of Molecular Systematics and Conservation Genetics, \\ Institute of Ecology and Biological Resources (VAST), \\ Cau Giay, Hanoi, Vietnam \\ ${ }^{3}$ Department of Experimental Biology, \\ Institute of Natural Products Chemistry (VAST), \\ Cau Giay, Hanoi, Vietnam
}

Corresponding author: N.M. Tam

E-mail: ngtam@hn.vnn.vn

Genet. Mol. Res. 13 (3): 5378-5386 (2014)

Received May 29, 2013

Accepted September 18, 2013

Published July 24, 2014

DOI http://dx.doi.org/10.4238/2014.July.24.17

\begin{abstract}
Dipterocarpus alatus (Dipterocarpaceae) is widely distributed in lowland forests in central and southern Vietnam, Cambodia, Laos, Myanmar, Philippines, Thailand, and India. Due to over-exploitation and habitat destruction, the species is now threatened. The genetic variation within and among populations of $D$. alatus was investigated on the basis of 9 microsatellite (single sequence repeat, SSR) loci. In all, 268 sampled trees from 10 populations in central and southern Vietnam were analyzed in this study. The SSR data showed
\end{abstract}


a high genetic variability within populations with an average of $H_{\mathrm{O}}$ $=0.209$ and $H_{\mathrm{E}}=0.239$. Genetic differentiation among populations was high $\left(F_{\mathrm{ST}}=0.266\right)$, indicating limited gene flow $\left(N_{\mathrm{m}}=0.69\right)$. Analysis of molecular variance showed that most genetic variation was within populations $(74.96 \%)$. This study highlights the importance of conserving the genetic resources of $D$. alatus species.

Key words: Dipterocarpus alatus; Genetic variation; Species conservation; SSR markers

\section{INTRODUCTION}

Dipterocarpus alatus, a species of the Dipterocarpaceae family, is believed to be restricted to central and southern Vietnam, Cambodia, Laos, Myanmar, Philippines, Thailand, and India (Nghia, 2005). This species is bisexual and insect-pollinated. Flowers are large, actinomorphic and scented. Fruiting appears almost every year, with fruit maturation occurring between March and April. The fruit consists of a single-seeded nut with a wing-like calyx. Seeds are dispersed by wind. D. alatus is an important timber tree and plays a dominant role in the ecology and economics of lowland rain forests in Vietnam. The wood of D. alatus is used for construction purposes such as plywoods, illumination, and waterproofing baskets and boats. Resin is used in paint, varnish, and lacquer. The species is widely distributed in evergreen and dry deciduous forests on the ancient alluvial rocks, granite, and basalt rocks that have low relief and a gentle slope, where water levels rise and fall rapidly during both dry and rainy seasons. The species prefers humidity of $75-85 \%$; precipitation, $1500-2200 \mathrm{~mm}$; mean annual temperature, $25^{\circ}-27^{\circ} \mathrm{C}$; and a dry season lasting 4-6 months.

Due to the exploitation of $D$. alatus for its valuable timber and resin by local people and forestry enterprises, its habitats are heavily affected by deforestation, forest fragmentation, and unsustainable management such as selective logging. Logging results in intense fragmented habitats and low-density populations. This threatens the long-term survival of the D. alatus genetic resource.

Conservation and management of a species requires information on the ecological and genetic diversity within and among populations. In order to obtain such information, especially a better understanding of genetic processes, powerful biological techniques are required. Organellar genomes (chloroplast and mitochondrial) are uniparentally inherited. Chloroplast is inherited via pollen, whereas mitochondria are inherited via seeds. Therefore, organellar DNA markers have been used for genetic differentiation between populations. Microsatellite markers (single sequence repeat, SSRs) are useful to analyze the effective pollen flow and seed dispersal within populations. Thus, these markers (high polymorphics) have been used for studies on gene flow, genetic structure, and mating systems (Ujino et al., 1998; Iwata et al., 2000; Takeuchi et al., 2004; Pandey and Geburek, 2009).

The evolutionary potential of a species depends on its genetic variation. Understanding the amount of genetic diversity provides information for the development of conservation strategies and sustainable utilization of a species. The objective of this study was to use SSRs as genetic markers to investigate the level of genetic variability within and between populations of $D$. alatus, and to provide guidelines for the conservation, management, and restoration of this species to the Protection Forestry Department, Vietnam. 


\section{MATERIAL AND METHODS}

\section{Plant materials}

This research was carried out in 10 sites, 4 in Dong Nai Province, and 1 each in Binh Phuoc, Tay Ninh, Ba Ria-Vung Tau, Phu Yen and Dak Lak, and Con Dao Islands (Figure 1; Table 1).

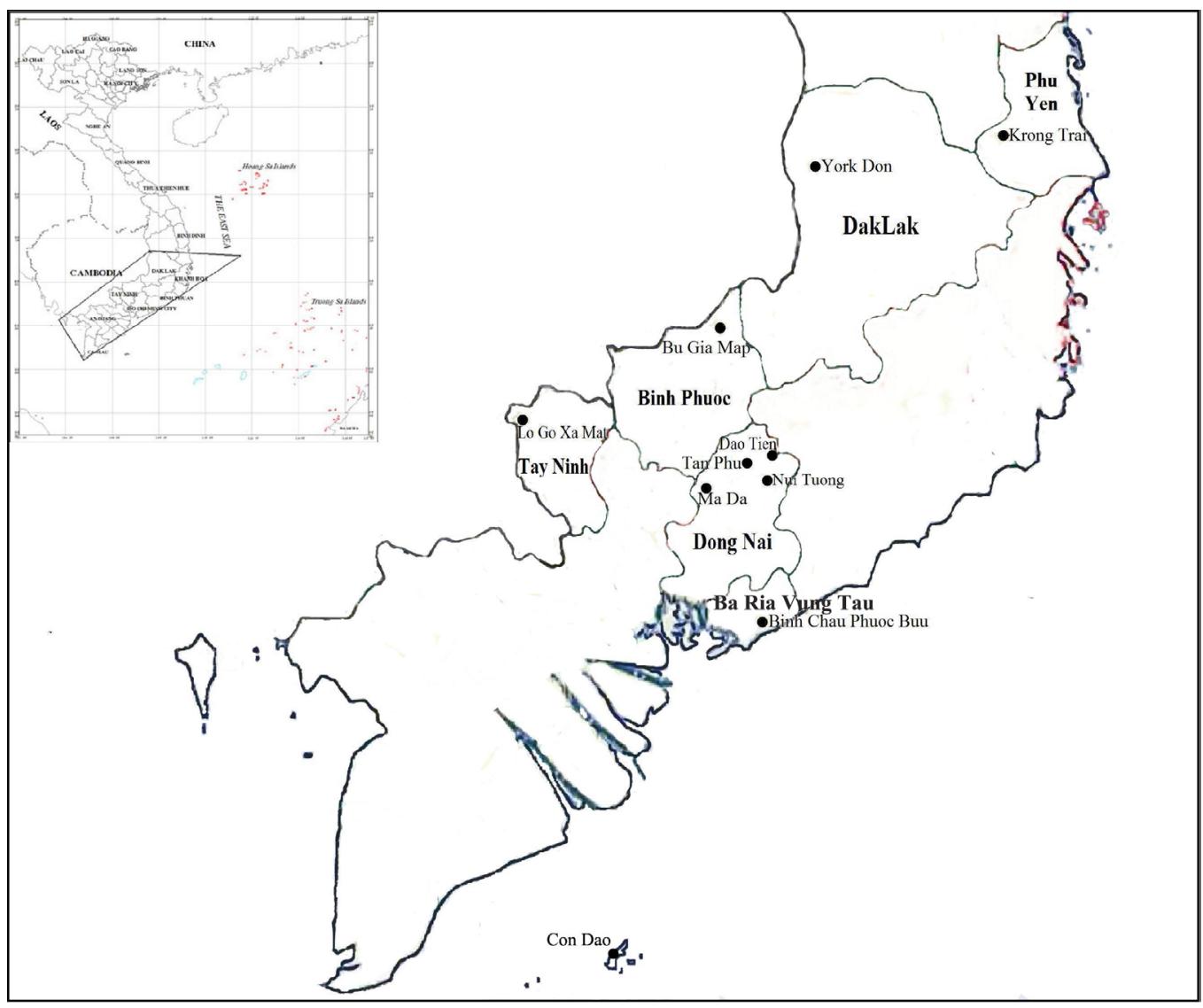

Figure 1. Study sites of Dipterocarpus alatus.

The original vegetation at all of these sites has been greatly affected by human activities, including exploitation for commerce, firewood collection, and construction. Some areas of the native vegetations at Lo Go Xa Mat (Tay Ninh), Bu Gia Map (Binh Phuoc), Binh Chau Phuoc Buu (Ba Ria-Vung Tau), and Con Dao Islands have been destroyed because of agricultural expansion. However, three strata also characterize these vegetation structures. These lead to the alteration of the spatial distribution and age class structure of trees in these sites. 
Table 1. Collection locations of Dipterocarpus alatus sample analysis.

\begin{tabular}{lclccc}
\hline Population & Sample size & Collection locality & Altitude & Latitude & Longitude \\
\hline Ma Da & 32 & Vinh Cuu, Dong Nai & $129 \mathrm{~m}$ & $11^{\circ} 12^{\prime} \mathrm{N}$ & $107^{\circ} 09^{\prime} \mathrm{E}$ \\
Dao Tien & 23 & Cat Tien, Dong Nai & $120 \mathrm{~m}$ & $11^{\circ} 44^{\prime} \mathrm{N}$ & $107^{\circ} 27^{\prime} \mathrm{E}$ \\
Tan Phu & 31 & Dinh Quan, Dong Nai & $80 \mathrm{~m}$ & $11^{\circ} 05^{\prime} \mathrm{N}$ & $107^{\circ} 24^{\prime} \mathrm{E}$ \\
Nui Tuong & 27 & Cat Tien, Dong Nai & $130 \mathrm{~m}$ & $11^{\circ} 25^{\prime} \mathrm{N}$ & $107^{\circ} 17^{\prime} \mathrm{E}$ \\
Bu Gia Map & 33 & Bu Gia Map, Binh Phuoc & $467 \mathrm{~m}$ & $12^{\circ} 13^{\prime} \mathrm{N}$ & $107^{\circ} 10^{\prime} \mathrm{E}$ \\
Con Dao & 29 & Con Dao Islands & $315 \mathrm{~m}$ & $8^{\circ} 40^{\prime} \mathrm{N}$ & $106^{\circ} 39^{\prime} \mathrm{E}$ \\
Binh Chau Phuoc Buu & 19 & Xuyen Moc, Ba Ria-Vung Tau & $100 \mathrm{~m}$ & $10^{\circ} 28^{\prime} \mathrm{N}$ & $107^{\circ} 35^{\prime} \mathrm{E}$ \\
Lo Go Xa Mat & 20 & Tan Bien, Tay Ninh & $10 \mathrm{~m}$ & $11^{\circ} 21^{\prime} \mathrm{N}$ & $106^{\circ} 02^{\prime} \mathrm{E}$ \\
York Don & 30 & Buon Don, Dak Lak & $230 \mathrm{~m}$ & $12^{\circ} 49^{\prime} \mathrm{N}$ & $107^{\circ} 34^{\prime} \mathrm{E}$ \\
Krong Trai & 24 & Son Hoa, Phu Yen & $158 \mathrm{~m}$ & $13^{\circ} 03^{\prime} \mathrm{N}$ & $108^{\circ} 51^{\prime} \mathrm{E}$ \\
\hline
\end{tabular}

In this study, the inner barks from 19 to 33 mature trees $(>25 \mathrm{~cm}$ dbh) were randomly sampled for the 10 populations, representing the natural range of D. alatus in Vietnam. The samples were placed into plastic bags with silica gel in the field; transferred to Laboratory of Molecular Biology, Vietnam National Museum of Nature; and stored at $-30^{\circ} \mathrm{C}$ until DNA extraction. The samples were identified on the basis of previous taxonomic treatments of collected specimens from these populations.

\section{DNA extraction}

Total DNA was extracted from the samples by using the modified CTAB method proposed by Doyle and Doyle (1987). Liquid nitrogen was added to about $100 \mathrm{mg}$ of each sample, which was then ground by hand. Total DNA amount was determined using fluorimetry and then diluted to a concentration of $10 \mathrm{ng} / \mu \mathrm{L}$.

\section{DNA amplification for SSRs}

Polymerase chain reaction (PCR) was performed using $25 \mu \mathrm{L}$ PCR buffer (Qiagen), $2.5 \mathrm{mM} \mathrm{MgCl} 2,2 \mathrm{mM}$ of each dNTP, $0.5 \mathrm{pM}$ of each primer, $0.5 \mathrm{U}$ Taq DNA polymerase (Qiagen) and 50 ng template DNA. In all, 9 SSR primer pairs were used in this study (Table 2).

\begin{tabular}{|c|c|c|c|c|c|}
\hline Locus & Repeat motif & Primer sequences & $\begin{array}{l}\text { PCR product } \\
\text { length }\end{array}$ & $\begin{array}{c}\text { Annealing } \\
\text { temperature }\left({ }^{\circ} \mathrm{C}\right)\end{array}$ & GenBank accession No. \\
\hline Dipt01 & $(\mathrm{AG})_{15}$ & $\begin{array}{l}\text { 5'-CTTCCCTAAATTCCCCAATGTT-3' } \\
\text { 5'-TAATGGTGTGTGTACCAGGCAT-3' }\end{array}$ & 193 & 55 & Isagi et al., 2002 \\
\hline Dipt03 & $(\mathrm{GA})_{24}$ & $\begin{array}{l}\text { 5'-ACAATGAAACTTGACCACCCAT-3' } \\
\text { 5'-CAAAAGGACATACCAGCCTAGC-3' }\end{array}$ & 226 & 56 & Isagi et al., 2002 \\
\hline Dipt04 & $(\mathrm{AG})_{15}$ & $\begin{array}{l}\text { 5'-TAGGGCATATTGCTTTCTCATC-3' } \\
\text { 5'-CTTATTGCAGTCATCAAGGGAA-3' }\end{array}$ & 214 & 55 & Isagi et al., 2002 \\
\hline Dipt05 & $(\mathrm{GA})_{25}$ & $\begin{array}{l}\text { 5'-TCTCAAAATCTGCAAAGACAGC-3' } \\
\text { 5'-CCATAGTCATCACCTCTAATGGTC-3' }\end{array}$ & 293 & 55 & Isagi et al., 2002 \\
\hline Dipt06 & $(\mathrm{TA})_{8}$ & $\begin{array}{l}\text { 5'-TGGCAAACAAGCTACTGTTCAT-3' } \\
\text { 5'-CATGGGTTTAGCAACCTACACA-3' }\end{array}$ & 258 & 55 & Isagi et al., 2002 \\
\hline Dipt07 & $(\mathrm{AC})_{9}$ & $\begin{array}{l}\text { 5'-CAGGAGGGGAATATGGAAAA-3' } \\
\text { 5'-AAGTCGTCATCTTTGGATTGC-3' }\end{array}$ & 120 & 54 & Isagi et al., 2002 \\
\hline Dipt08 & $(\mathrm{GA})_{6}$ & $\begin{array}{l}\text { 5'-ATGCTTACCACCAATGTGAATG-3' } \\
\text { 5'-CTCGCAGCAGAACAACTTTCTA-3' }\end{array}$ & 170 & 55 & Terauchi, 1994 \\
\hline Shc07 & $\begin{array}{c}(\mathrm{CT})_{8} \mathrm{CA}(\mathrm{CT})_{5} \\
\mathrm{CACCC}(\mathrm{CTCA})_{3} \\
\mathrm{CT}(\mathrm{CA})_{10}\end{array}$ & $\begin{array}{l}\text { 5'-ATGTCCATGTTTGAGTG-3' } \\
\text { 5'-CATGGACATAAGTGGAG-3' }\end{array}$ & 169 & 54 & Ujino et al., 1998 \\
\hline Shc11 & $\begin{array}{c}(\mathrm{CT})_{4} \mathrm{TT}^{\mathrm{T}} \\
(\mathrm{CT})_{5}\end{array}$ & $\begin{array}{l}\text { 5'-ATCTGTTCTTCTACAAGCC-3' } \\
\text { 5'-TTAGAACTTGAGTCAGATC-3' }\end{array}$ & 166 & 54 & Ujino et al., 1998 \\
\hline
\end{tabular}


The reaction mixture was subjected to amplification in the GeneAmp PCR System 9700 (Applied Biosystems) as follows: an initial denaturing step at $94^{\circ} \mathrm{C}$ for $2 \mathrm{~min}, 40$ cycles of $1 \mathrm{~min}$ at $94^{\circ} \mathrm{C}, 1 \mathrm{~min}$ annealing for each primer pair at $54^{\circ}-56^{\circ} \mathrm{C}, 1 \mathrm{~min}$ extension at $72^{\circ} \mathrm{C}$, and a final extension for $10 \mathrm{~min}$ at $72^{\circ} \mathrm{C}$; the samples were then stored at $4^{\circ} \mathrm{C}$. The amplification products were separated using a Sequi-Gen GT DNA electrophoresis system. Allele sizes were determined against the internal size standard and on QIAxcel Advanced System.

\section{DNA analysis}

Genetic parameters were calculated using the Arlequin 3.1 program (Excoffier et al., 2005), including the number of alleles $\left(N_{\mathrm{A}}\right)$ per locus, observed $\left(H_{\mathrm{O}}\right)$ and expected $\left(H_{\mathrm{E}}\right)$ heterozygosities, the coefficient of excesses of homozygotes or heterozygotes compared with panmictic expectations within populations $\left(F_{\mathrm{IS}}\right)$, and the genetic differentiation $\left(F_{\mathrm{ST}}\right)$ between populations. Exact tests of deviation from the Hardy-Weinberg equilibrium for all loci and among populations were performed at the significance level $(\mathrm{P})=0.05 . F_{\mathrm{ST}}$ values were also used to estimate the levels of gene flow between populations. Significance testing for variance components in analysis of molecular variance (AMOVA) was implemented on the basis of 1000 permutations. Genetic distances and identities, and UPGMA cluster analysis of genetic distances were generated to determine the genetic association among populations by using TFPGA (Miller, 1997).

\section{RESULTS}

\section{Genetic variation}

The 9 SSR markers produced a total of 38 clear bands ranging in size from 100 to 295 bp, across all 268 trees of the 10 D. alatus populations. All 9 SSR loci were polymorphic in $D$. alatus species. The number of polymorphic loci varied among populations. The proportion of polymorphic loci was high $(100 \%)$ in all populations, except 3 populations $(77.8 \%$ for Con Dao and Binh Chau Phuoc Buu, and 88.9\% for Krong Trai). At the species level, 4 alleles were revealed at 3 loci (Dipt03, Dipt04, and Dipt06); 3 at 4 loci (Dipt01, Dipt05, Dipt08, and Shc07); and 2 at Dipt07 and Shc11. The values of genetic diversity included $N_{\mathrm{A}}=2.2, H_{\mathrm{O}}=$ 0.209 , and $H_{\mathrm{E}}=0.239$ (Table 2). The most common alleles (allelic frequencies, $>0.8$ ) were revealed at 6 polymorphic loci for 3 populations (Dao Tien, Nui Tuong, and Tan Phu); 7 for 5 populations (Bu Gia Map, Ma Da, York Don, Lo Go Xa Mat, and Krong Trai); and 8 and 9 for Binh Chau Phuoc Buu and Con Dao, respectively. At the population level, 4 populations in Dong Nai had higher levels of genetic diversity than the remaining populations (Table 3).

In all the studied populations, except for 3 populations; Ma Da, Tan Phu, and Lo Go Xa Mat, there were positive fixation index values $\left(F_{\text {IS }}>0.1\right)$, indicating an excess of homozygotes and inbreeding. Two populations (Bu Gia Map and Con Dao) had positive values $\left(F_{\text {IS }}>\right.$ 0.2 ) and suggested a remarkable decrease in hetezygogotes within these populations.

\section{Genetic structure}

The results of AMOVA revealed that $74.96 \%$ of the total variation was due to the dif- 
ference within populations. This was higher than the proportion among populations (Table 4). The variation between populations was significant in D. alatus $(25.04 \%$; $\mathrm{P}<0.001)$.

\begin{tabular}{|c|c|c|c|c|c|}
\hline Population & $\mathrm{N}$ & $N_{\mathrm{A}}$ & $H_{\mathrm{O}}$ & $H_{\mathrm{E}}$ & $F_{\text {IS }}$ \\
\hline $\mathrm{Ma} \mathrm{Da}$ & 32 & 2.3 & 0.281 & 0.283 & 0.005 \\
\hline Dao Tien & 23 & 2.5 & 0.252 & 0.298 & $0.157^{*}$ \\
\hline Tan Phu & 31 & 2.4 & 0.279 & 0.281 & 0.004 \\
\hline Nui Tuong & 27 & 2.6 & 0.248 & 0.291 & $0.149 *$ \\
\hline Bu Gia Map & 33 & 2.0 & 0.181 & 0.237 & $0.238^{* *}$ \\
\hline Lo Go-Xa Mat & 29 & 1.8 & 0.158 & 0.166 & 0.053 \\
\hline Binh Chau Phuoc Buu & 19 & 1.7 & 0.150 & 0.171 & 0.126 \\
\hline Con Dao & 20 & 2.1 & 0.161 & 0.205 & $0.218^{*}$ \\
\hline York Don & 30 & 2.3 & 0.174 & 0.213 & $0.187^{*}$ \\
\hline Krong Trai & 24 & 1.9 & 0.213 & 0.254 & $0.164 *$ \\
\hline Mean & 26.8 & 2.2 & 0.209 & 0.239 & 0.124 \\
\hline
\end{tabular}

$\mathrm{N}=$ population size; $N_{\mathrm{A}}=$ mean number of alleles per locus; $H_{\mathrm{O}}$ and $H_{\mathrm{E}}=$ mean observed and expected heterozygosities, respectively; $F_{\mathrm{IS}}=$ Wright's inbreeding coefficient with $* \mathrm{P}<0.05, * * \mathrm{P}<0.01$.

Table 4. Analysis of molecular variance in Dipterocarpus alatus from ten populations.

\begin{tabular}{lrcccc}
\hline Source of variation & d.f. & Sum of squares & Variance component & Total variation (\%) & P value \\
\hline Among populations & 9 & 188.660 & 0.361 & 25.04 & $<0.001$ \\
Within populations & 542 & 586.345 & 1.082 & 74.96 & \\
Total & 551 & 775.05 & 1.443 & & \\
\hline
\end{tabular}

The population pairwise differentiations (generated from AMOVA) indicated that most of the populations were significantly differentiated $(\mathrm{P}<0.05) . F_{\mathrm{ST}}$ values ranged from 0.053 to 0.492 , except for population pairs in Dong Nai Province, which had $F_{\mathrm{ST}}$ values from 0.024 to $0.027(\mathrm{P}>0.05$; see Table 5). These low differentiation values suggest gene exchanges between the 4 populations together in the same province. The results of AMOVA showed $F_{\text {ST }}$ value of 0.266 and gene flow $N_{\mathrm{m}}$ of 0.69 in the D. alatus species.

Table 5. Population pairwise $F_{\mathrm{ST}}$ and significant values.

\begin{tabular}{|c|c|c|c|c|c|c|c|c|c|c|}
\hline & $\mathrm{BC}$ & BG & MD & DT & $\mathrm{CD}$ & NT & TP & YD & LG & KT \\
\hline BC & & + & + & + & + & + & + & + & + & + \\
\hline BG & 0.338 & & + & + & + & + & + & + & + & + \\
\hline MD & 0.460 & 0.229 & & - & + & - & - & + & + & + \\
\hline DT & 0.440 & 0.215 & 0.026 & & + & - & - & + & + & + \\
\hline CD & 0.216 & 0.405 & 0.489 & 0.472 & & + & + & + & + & + \\
\hline NT & 0.439 & 0.225 & 0.024 & 0.027 & 0.470 & & - & + & + & + \\
\hline $\mathrm{TP}$ & 0.464 & 0.230 & 0.025 & 0.024 & 0.492 & 0.025 & & + & + & + \\
\hline YD & 0.304 & 0.111 & 0.292 & 0.272 & 0.327 & 0.277 & 0.296 & & + & + \\
\hline LG & 0.327 & 0.120 & 0.301 & 0.278 & 0.351 & 0.283 & 0.305 & 0.190 & & + \\
\hline $\mathrm{KT}$ & 0.415 & 0.053 & 0.263 & 0.246 & 0.433 & 0.257 & 0.265 & 0.156 & 0.167 & \\
\hline
\end{tabular}

$\mathrm{BC}=$ Binh Chau Phuoc Buu; BG = Bu Gia Map; MD = Ma Da; DT = Dao Tien; CD = Con Dao; NT = Nui Tuong; $\mathrm{TP}=$ Tan Phu; $\mathrm{YD}=$ York Don, $\mathrm{LG}=$ Lo Go Xa Mat; KT $=$ Krong Trai. Significance level $=0.05$.

\section{Genetic distances and cluster analysis}

Table 6 shows the pairwise Nei's (1972) genetic distances and genetic identities be- 
tween populations. The largest genetic distance $(0.298)$ was found between populations of Ma $\mathrm{Da}$ and Con Dao, and the smallest (0.012) between populations of Nui Tuong and Dao Tien. Similar to the results of genetic distances, the largest identity (0.987) was also recorded between populations of Nui Tuong and Dao Tien and the smallest (0.742) between populations of Con Dao and Ma Da. The mean values of genetic distance between the studied populations ranged from 0.012 to 0.298 , with an average of 0.125 . The mean value of genetic identity between the populations ranged from 0.742 to 0.987 , with an average of 0.819 . The obtained value of genetic distance indicated low level of differentiation within populations in Dong Nai Province.

\begin{tabular}{|c|c|c|c|c|c|c|c|c|c|c|}
\hline & $\mathrm{BC}$ & BG & MD & DT & $\mathrm{CD}$ & NT & $\mathrm{TP}$ & YD & LG & KT \\
\hline $\mathrm{BC}$ & & 0.839 & 0.762 & 0.780 & 0.898 & 0.780 & 0.769 & 0.904 & 0.897 & 0.841 \\
\hline BG & 0.175 & & 0.893 & 0.897 & 0.843 & 0.892 & 0.891 & 0.959 & 0.955 & 0.957 \\
\hline MD & 0.271 & 0.113 & & 0.982 & 0.742 & 0.982 & 0.986 & 0.864 & 0.853 & 0.871 \\
\hline DT & 0.248 & 0.110 & 0.015 & & 0.761 & 0.987 & 0.985 & 0.872 & 0.862 & 0.878 \\
\hline $\mathrm{CD}$ & 0.111 & 0.171 & 0.298 & 0.273 & & 0.761 & 0.748 & 0.899 & 0.892 & 0.845 \\
\hline NT & 0.248 & 0.114 & 0.015 & 0.012 & 0.273 & & 0.986 & 0.870 & 0.860 & 0.872 \\
\hline $\mathrm{TP}$ & 0.263 & 0.115 & 0.013 & 0.014 & 0.290 & 0.013 & & 0.860 & 0.849 & 0.870 \\
\hline YD & 0.101 & 0.042 & 0.146 & 0.136 & 0.106 & 0.139 & 0.151 & & 0.896 & 0.944 \\
\hline LG & 0.108 & 0.046 & 0.159 & 0.148 & 0.114 & 0.151 & 0.164 & 0.107 & & 0.938 \\
\hline KT & 0.173 & 0.047 & 0.138 & 0.131 & 0.169 & 0.137 & 0.140 & 0.058 & 0.064 & \\
\hline
\end{tabular}

$\mathrm{BC}=$ Binh Chau Phuoc Buu; BG = Bu Gia Map; MD = Ma Da; DT = Dao Tien; CD = Con Dao; NT = Nui Tuong; $\mathrm{TP}=$ Tan Phu; YD = York Don; LG = Lo Go Xa Mat; KT = Krong Trai.

An UPGMA dendrogram (Figure 2) revealed genetic relationships among all the populations investigated on the basis of the Nei's (1972) matrix of genetic distances among populations (Table 6). A total of 10 populations were divided into 3 major groups: the first one corresponding to 4 populations in Dong Nai Province and showing a close relationship to each other with the lowest genetic distances (0.012-0.015), the second one corresponding to 4 populations of York Don (Dak Lak Province), Lo Go Xa Mat (Tay Ninh), Bu Gia Map (Binh Phuoc), and Krong Trai (Phu Yen). The 2 remaining populations of Binh Chau Phuoc Buu and Con Dao were clustered together, with high genetic distance (0.111). According to Mantel tests, the correlation between genetic distance and geographic distance was significant $(\mathrm{R}=0.501 ; \mathrm{P}<0.05)$.

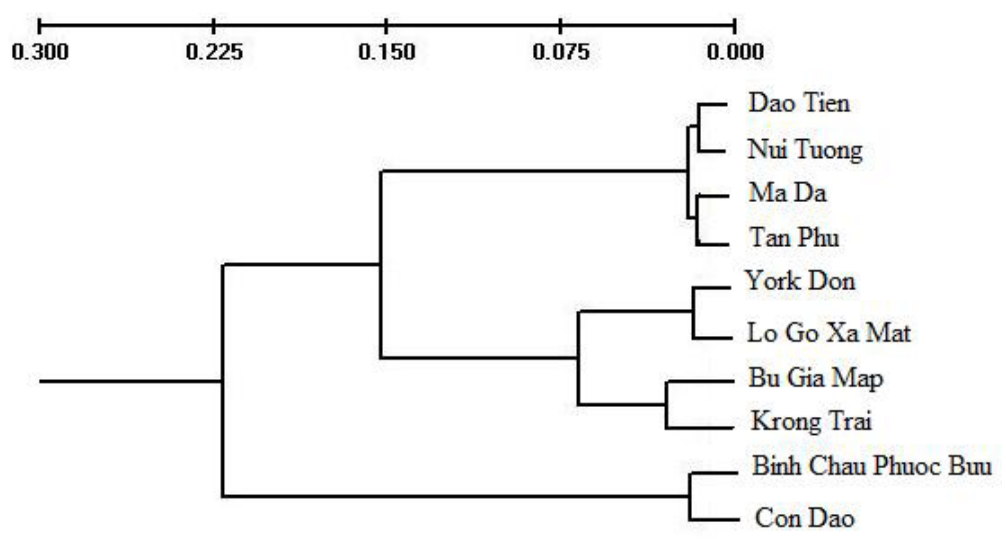

Figure 2. UPGMA dendrogram based on Nei's 1972 genetic distance among the ten populations. 


\section{DISCUSSION}

Outcrossing species with a great potential for genetic movement will maintain the high levels of genetic diversity within populations and species (Hamrick, 1983; Hamrick and Godt, 1989). Information on the high values of genetic diversity in dipterocarp species such as Shorea lumutensis (Lee et al., 2004; Boshier, 2011), S. leprosula (Lee et al., 2000; Rimbawanto and Isoda, 2001; Keiya et al., 2001) and population levels was reported previously. Our results showed that $D$. alatus had high levels of genetic diversity within populations, mean $H_{\mathrm{O}}=0.209(0.150$ $0.281)$ and $H_{\mathrm{E}}=0.239(0.166-0.298)$. This reflects species ecology and history. The species is regionally distributed, has a long-life, has high fecundity, predominantly outcrosses, pollinated by insects (Appanah and Chan, 1981; Chan, 1981), and late successional. Seeds are dispersed by wind and water (Ashton, 1982). However, some studied populations of D. alatus showed lower levels of genetic diversity (e.g., Phu Quoc, Binh Chau Phuoc Buu, Lo Go Xa Mat, York Don, and $\mathrm{Bu}$ Gia Map) than the remaining populations (Krong Trai and 4 populations in Dong Nai Province). This might be due to smaller sample sizes, resulting, in part, from human activities (e.g., logging). Small populations might result inbreeding, which can reduce genetic diversity.

AMOVA revealed that most genetic diversity was found within the $D$. alatus populations. The genetic diversity partitioned among populations was significant $(\mathrm{P}<0.001)$. The overall degree of population differentiation was higher in D. alatus $\left(F_{\mathrm{ST}}=0.266\right)$ compared with some other dipterocarp species studied, such as Dryobalanops aromatica $\left(G_{\mathrm{ST}}=0.067\right.$; Lim et al., 2001), Shorea leprosula $\left(G_{\mathrm{ST}}=0.117\right.$; Lee et al., 2000) and Shorea lumutensis $\left(G_{\mathrm{ST}}\right.$ $=0.048$; Lee et al., 2004). Our research showed that $73.4 \%$ of the observed genetic variability was contained within populations, and $26.6 \%$ was due to the difference among populations. These results are in contradiction with the expectation of low variability among populations of long-lived and outcrossing species (Hamrick and Godt, 1989). The gene flow via limited pollen and seed dispersal plays an important role for these results. Dipterocarp species are insect-pollinated (Appanah and Chan, 1981; Dayanandan et al., 1990). Moreover, dipterocarp species growing in swamps and river banks have fruits with short sepals, and their seeds are dispersed by water. Only populations in Nui Tuong, Dao Tien, Tan Phu, and Ma Da, which were located close to the Dong Nai River showed low and none significant genetic differentiation $\left(F_{\mathrm{ST}}=0.012-0.018, \mathrm{P}>0.05\right)$. This suggests a high degree of gene flow between these populations and indicates that differentiation in these populations is not due to restricted gene flow. High degrees of differentiation between populations belonging to other provinces, indicates low gene flow $\left(N_{\mathrm{m}}<1\right)$. A barrier to gene flow is reflected by significant differentiation $(25.04 \% ; \mathrm{P}<0.001)$ in $D$. alatus species.

In conclusion, $D$. alatus maintained the relatively high levels of genetic variability within populations and a high level of genetic population differentiation. From conservation of these species, effective management strategies should be considered for both in situ and ex situ activities. For example, logging activities should be controlled. Less gene flow resulting from over-exploitation might reduce population viability through, for example, increased inbreeding, genetic differentiation, and genetic erosion by genetic drift.

\section{ACKNOWLEDGMENTS}

\footnotetext{
Research supported by NAFOSTED (\#106.15-2011.74).
} 


\section{REFERENCES}

Appanah S and Chan HT (1981). Thrips: the pollinator of some dipterocarps. Malaysian For. 44: 234-252.

Ashton PS (1982). Dipterocarpaceae. In: Flora Malesiana Series 1 (Van Steenis CGGJ, ed.). Martinus Nijhoff Publishers, The Hague, 9: 237-552.

Boshier D (2011). Shorea lumutensis: Genetic Variation and Conservation. A Case Study and Teacher's Notes. In: Forest Genetic Resources Training Guide (Boshier D, Bozzano M, Loo J and Rudebjer P, eds.). Bioversity International, Rome, 13.

Chan HT (1981). Reproductive biology of some Malaysia dipterocarp III. Breeding systems. Malaysia For. 44: 28-36.

Dayanandan S, Attygalla DNC, Abeygunasekara AWWL, Gunatilleke IAUN, et al. (1990). Phenology and Floral Morphology in Relation to Pollination of Some Sri Lankan Dipterocarps. In: Reproductive Ecology of Tropical Forest Plants (Bawa KS and Hadley M, eds.). UNESCO, Paris and Parthenon Publishing Group, Carnforth, 103-133.

Doyle JJ and Doyle JL (1987). A rapid DNA isolation procedure for small qualities of fresh leaf material. Phytochemical Bull. 19: 11-15.

Excoffier L, Laval G and Schneider S (2005). Arlequin (version 3.0): an integrated software package for population genetics data analysis. Evol. Bioinform. Online 1: 47-50.

Hamrick JL (1983). The Distribution of Genetic Variation Within and Among Natural Plant Populations. In: Genetics and Conservation (Schonewald-Cox CA, Chambers SM, MacBryde B and Thomas L, eds.). The Benjamin/Cumming Publishing Company, Inc., Menlo Park, 335-348.

Hamrick JL and Godt MJW (1989). Allozyme Diversity in Plant Species. In: Plant Population Genetics, Breeding and Genetic Resources (Brown ADH, Cler MT, Kahler AL and Weir BS, eds.). Sinauer, Sunderland, 43-63.

Isagi V, Kenta T and Nakashizuka T (2002). Microsatellite loci for a tropical emergent tree, Dipterocarpus tempehes V. S1 (Dipterocarpaceae). Mol. Ecol. Notes 2: 12-13.

Iwata H, Konuma A and Tsumura Y (2000). Development of microsatellite markers in the tropical tree Neobalannocarpus heimii (Dipterocarpaceae). Primer Notes 1684-1685.

Lee SL, Wickneswari R, Mahani MC and Zakri AH (2000). Genetic diversity of a tropical species, Shorea leprosula Miq. (Dipterocarpaceae) in Malaysia: implications for conservation of genetic resources and tree improvement. Biotropica 32: $213-224$

Lee SL, Ng KKS, Lee CT, Norwati M, et al. (2004). Shorea lumutensis, an endangered dipterocarp with high levels of genetic diversity but low population differentiation. Conf. For. Forest Prod. Res. 166-173.

Lim LS, Wickneswari R, Lee SL and Latiff A (2001). Genetic Structure of Natural Populations of Dryobalanops aromatic Gaertn. F. (Dipterocarpaceae) in Peninsular Malaysia Using Microsatellite DNA Markers. In: In-Situ and Ex-Situ Conservation of Commercial Tropical Trees (Thielges BA, Sastrapradja SD and Rimbawanto A, eds.). Gadjah Mada University, Yogyekarta, 309-324.

Keiya I, Irsyal Y, Anto R and Istiana P (2001). Estimation of Genetic Variation of Drybalanops oblongifolia Dyer. (Dipterocarpaceae) Planted in Peninsular Malaysia. In: In-Situ and Ex-Situ Conservation of Commercial Tropical Trees (Thielges BA, Sastrapradja SD and Rimbawanto A, eds.), Gadjah Mada University, Yogyekarta, 377-384.

Miller MP (1997). Tools for Population Genetic Analysis (TFPGA) 1.3: A Windows Program for the Analysis of Allozyme and Molecular Population Genetic Data. Distributed by the author.

Nei M (1972). Genetic distance between populations. Am. J. Bot. 72: 1590-1597.

Nghia NH (2005). Dipterocarps of Vietnam. Agricultural Publishing House, Hanoi.

Pandey M and Geburek T (2009). Successful cross-amplification of Shorea microsatellites reveals genetic variation in the tropical tree, Shorea robusta Gaertn. Hereditas 146: 29-32.

Rimbawanto A and Isoda AK (2001). Genetic Structure of Shorea leprosula in a Single Population Revealed by Microsatellite Markers. In: In-Situ and Ex-Situ Conservation of Commercial Tropical Trees (Thielges BA, Sastrapradja SD and Rimbawanto A, eds.). Gadjah Mada University, Yogyekarta, 331-338.

Takeuchi Y, Ichikawa S, Konuma A, Tomaru N, et al. (2004). Comparison of the fine-scale genetic structure of three dipterocarp species. Heredity 92: 323-328.

Terauchi R (1994). A polymorphic microsatellite marker from the tropical tree Dryobalanops lanceolata (Dipterocarpaceae). Jpn. J. Genet. 69: 567-576.

Ujino T, Kawahara T, Tsumura Y, Nagamitsu T, et al. (1998). Development and polymorphism of simple sequence repeat DNA markers for Shorea curtisii and other Dipterocarpaceae species. Heredity 81: 422-428. 